\title{
PERÍCIA CONTÁBIL: UMA FERRAMENTA DE COMBATE AO CRIME ORGANIZADO
}

\author{
FORENSIC ACCOUNTING: A TOOL TO COMBAT ORGANIZED CRIME
}

\section{PERICIA CONTABLE: UNA HERRAMIENTA DE COMBATE AL CRIMEN ORGANIZADO}

\section{IDALBERTO JOSÉ DAS NEVES JÚNIOR}

Mestre em Gestão do Conhecimento e Tecnologia da Informação pela Universidade Católica de Brasília - UCB. Bacharel em Ciências Contábeis. Tecnológo em Processamento de Dados. Especialista nas áreas de Administração Contábil e Financeira, de Análista de Sistemas, de Metodologia do Ensino Superior, de Aprendizagem Cooperativa em Estilo Salesiano de Educar. Professor e Assessor do Curso de Ciências Contábeis da UCB. Pesquisador nas áreas de Perícia Contábil, Controladoria e Ensino da Contabilidade. Gerente de Divisão da Diretoria de Controladoria do Banco do Brasil. ENDEREÇO: Campus I - QS 07 Lote 01

EPCT, Águas Claras - CEP: 71966-700 - Taguatinga/DF - Telefone: (61) 3356-9000.

\section{E-mail:jneves@ucb.br.}

\section{EVANDRO MARCOS DE SOUZA MOREIRA}

Bacharel em Ciências Contábeis pela Universidade Católica de Brasília - UCB. Especialista em Contabilidade Governamental pela Universidade Cândido Mendes - UCAM. Servidor Público do Governo do Distrito Federal-DF - Especialista da Carreira de Assistencial do DF/Contador. Assessor Técnico da Secretaria de Estado de Desenvolvimento Social e

Transferência de Renda do Distrito Federal. E-mail: emsm@hotmail.com.

\section{RESUMO}

No Brasil e no mundo, devido principalmente à ausência do Estado no cumprimento do seu papel de garantidor da lei e da ordem, as organizações criminosas cresceram 
significativamente, e as suas ações passaram a ocorrer de formas planejadas e estratégicas. Para combatê-las e reprimi-las, a Perícia Contábil, materializada nos laudos periciais elaborados pelos peritos criminalistas, surge como importante ferramenta de Inteligência. Nesse contexto, o objetivo desta pesquisa foi identificar a relevância da Perícia Contábil como meio de prova para a solução de controvérsias relativas ao crime organizado. Para tanto, houve a realização de pesquisa de campo por meio de questionário aplicado aos Delegados, Escrivães e Agentes de Polícia das divisões da Diretoria de Combate ao Crime organizado - DCOR do Departamento de Polícia Federal. Também, houve a utilização de técnicas de estatística multivariada de análise de cluster para o estudo dos registros ( $K$ Means clusters do software SPSS), que resultou na formação de dois agrupamentos. Considerando a pesquisa de campo e o referencial teórico, verificou-se que a Perícia Contábil, no limite de suas atribuições, é um relevante meio de prova para a solução de controvérsias relativas ao crime organizado.

Palavras-chave: Perícia Contábil; Laudo Pericial Contábil; Lavagem de Dinheiro; Crime Organizado.

\section{ABSTRACT}

In Brazil and the world, mainly due to the absence of the state in fulfilling its role as keeper of law and order, criminal organizations have grown significantly, and its actions have begun to occur in a planned and strategic manner. In order to fight and repress them, Forensic Accounting, embodied in the forensic reports provided by expert criminologists, is emerging as an important tool for Intelligence. In this context, the objective of this research was to identify the relevance of the Forensic Accounting as a method of settling disputes related to organized crime. For this, field research was conducted through a questionnaire applied to the Delegates, Actuaries, and Police Agents of the divisions of the Directorate for Combating Organized Crime - DCOR Police Department - DPF. There was also the use of multivariate statistical techniques in the analysis of clusters for the study of records (KMeans clustering of SPSS), which resulted in the formation of two groups. Considering the field research and the theoretical reference, it was verified that Forensic Accounting, within the limit of his powers, is an important evidence for the settlement of disputes relating to organized crime.

Keywords: Forensic Accounting; Forensic Accounting Report; Money Laundering; Organized Crime. 


\section{RESUMEN}

En el Brasil y en el mundo, debido principalmente a la ausencia del Estado en el cumplimiento de su papel de garantizador de la ley y del orden, las organizaciones criminosas crecieron significativamente, y sus acciones pasaron a ocurrir de formas planificadas y estratégicas. Para combatirlas y reprimirlas, la Pericia Contable, materializada en los laudos periciales elaborados por los peritos criminalistas, surge como importante herramienta de Inteligencia. En ese contexto, el objetivo de esta pesquisa fue identificar la relevancia de la Pericia Contable como medio de prueba para la solución de controversias relativas al Crimen Organizado. Para tanto, hubo la realización de pesquisa de campo por medio de cuestionario aplicado a los Delegados, Escribanos y Agentes de policía de las divisiones de la Directoría de Combate al Crimen Organizado - DCOR del Departamento de Policía Federal. También, hubo la utilización de técnicas de estadística multi-variada de análisis de clúster para el estudio de los registros (K-Means clusters do software SPSS), que resultó en la formación de dos agrupamientos. Considerando la pesquisa de campo y el referencial teórico, fue verificado que la Pericia Contable, en el límite de sus atribuciones, es un relevante medio de prueba para la solución de controversias relativas al Crimen Organizado.

Palabras clave: Pericia Contable; Laudo Pericial Contable; Blanqueo de Dinero; Crimen Organizado.

\section{INTRODUÇÃO}

À medida que cresce o crime organizado no Brasil e no mundo, também aumenta a utilização e o aperfeiçoamento das técnicas de perícia criminal para combatê-lo. Dentre essas técnicas, destaca-se a Perícia Criminal Contábil como ferramenta na obtenção de provas e repressão dessas organizações criminosas.

O Procurador da República, Luiz Francisco de Souza, esclarece que o Estado Brasileiro está totalmente infectado pelo crime organizado.

O estado brasileiro, infelizmente, é um dos mais infiltrados pelo crime organizado. Nosso Estado está infiltrado por corruptos, traficantes, contrabandistas, lavadores de dinheiro, sonegadores, bicheiros, donos de bingos e outros criminosos de colarinho branco. São vários ramos da economia ocultos, movidos por capitalistas criminosos (SOUZA, 2004, p. 58).

Além de operarem de maneira sistêmica no território nacional, essas organizações criminosas também possuem ramificações internacionais. Diante desse contexto e do aper- 
feiçoamento das técnicas de Perícia Criminal para combater essas organizações, o problema a ser pesquisado no decorrer deste trabalho pode ser assim sintetizado:

Qual é a relevância da Perícia Contábil - no âmbito criminal federal - para os usuários do laudo pericial no processo de investigação das práticas do crime organizado no Brasil na opinião de Delegados, Escrivães e Agentes de Polícia?

Considerando que o laudo pericial pode ser peça fundamental para condenar ou inocentar o réu, o qual responderá perante a autoridade competente designada nos autos do processo criminal, este estudo tem como objetivo identificar a relevância da Perícia Criminal Contábil como meio de prova para a solução de controvérsias relativas ao crime organizado no território nacional.

Para discussão e estudo do problema de pesquisa foram aplicados 35 questionários aos Delegados, Escrivães e Agentes de Polícia Federal. Foram colhidos 770 dados por meio da pesquisa de campo aplicada aos usuários da Perícia Contábil, especificamente nas divisões da Diretoria de Combate ao Crime Organizado do Departamento de Polícia Federal.

Este estudo assumiu como suposição que as investigações criminais, na maioria das vezes, são insuficientes para esclarecer os atos e fatos ilícitos praticados pelos infratores, e que a Perícia Contábil permite entender e esclarecer os crimes cometidos, uma vez que se espelha na busca de provas dos fatos ocorridos, além da necessidade expressa em lei de fazê-la.

\section{REVISÃO DA LITERATURA}

\subsection{Perícia Contábil Judicial}

A expressão Perícia advém do latim peritia, que em seu sentido próprio significa conhecimento, bem como experiência do expert. A Perícia Contábil é a verificação de fatos ligados ao patrimônio, visando oferecer opinião sobre questão proposta. Para emitir opinião realizam-se exames, vistorias, indagações, investigações, avaliações, arbitramentos, em suma, todo e qualquer procedimento necessário à opinião (SÁ, 2005, p. 14). D’Áuria (1953, p. 134) argumenta que "[...] a perícia é o testemunho de uma ou mais pessoas técnicas, no sentido de fazer conhecer um fato cuja existência não pode ser acertada ou juridicamente apreciada, senão apoiada em conhecimentos científicos ou técnicos".

Ornelas (2009. p. 33) relata que "a Perícia Contábil inscreve-se num dos gêneros de prova pericial, ou seja, é uma das provas técnicas a disposição das pessoas naturais ou jurídicas, e serve como meio de prova de determinados fatos contábeis ou de questões contábeis controvertidas".

Conforme noções conceituais de Magalhães, Souza e Favero (2004, p. 12), a perícia é "qualquer trabalho de natureza específica, cujo rigor na execução seja profundo. Dessa maneira, pode haver perícia em qualquer área científica ou até em determinadas situações empíricas". Mais adiante, exemplificam que, por outro lado, a natureza do processo é que 
a classificará, podendo ser de origem judicial, extrajudicial, administrativa ou operacional e, quanto à natureza dos fatos que a ensejam, pode ser classificada como criminal, contábil, médica, trabalhista etc.

No entendimento de Sá (2005, p. 63), a "Perícia Contábil judicial é a que visa servir de prova, esclarecendo o juiz sobre assuntos em litígio que merecem seu julgamento, objetivando fatos relativos ao patrimônio aziendal ou de pessoas". No processo judicial, de acordo com o Código de Processo Civil - CPC, como edita o artigo 145, o juiz será assistido por perito quando a prova do fato depender de conhecimento técnico ou científico. Conforme confere o art. 421 do Código de Processo Civil - CPC (BRASIL, 1993), após a admissão da prova pericial contábil, o juiz nomeará o perito, fixando-lhe, de imediato, o prazo para entrega do laudo.

O Conselho Federal de Contabilidade com a edição da Resolução CFC n ${ }^{\circ}$ 1.243/09 aprova a NBC TP 01 - Perícia Contábil, e, inicialmente, conceitua a Perícia Contábil da seguinte forma:

\begin{abstract}
A Perícia Contábil constitui o conjunto de procedimentos técnico-científicos destinados a levar à instância decisória elementos de prova necessários a subsidiar à justa solução do litígio ou constatação de um fato, mediante laudo pericial contábil e/ou parecer pericial contábil, em conformidade com as normas jurídicas e profissionais, e a legislação específica no que for pertinente (NBC TP 01).
\end{abstract}

Em seguida, essa mesma norma nos esclarece que a "Perícia no âmbito estatal é executada sob o controle de órgão do estado, tais como perícia administrativa das Comissões Parlamentares de Inquérito, de perícia criminal e do Ministério Público".

Em relação ao contexto das perícias contábeis na América Latina, Morais (2005), citando Gastelum (2002), descreve a atuação do perito contador no México, da seguinte forma:

\begin{abstract}
El Contador Público que actúa como perito contable en un juicio debe desarrollar su trabajo con total independencia e imparcialidad; además, debe aceptar su responsabilidad y contratar sus servicios con total profesionalismo, pues el resultado de su trabajo, es decidir el informe que emita, habrá de ser utilizado por el juez para interpretar las pruebas proporcionadas y llegar a una conclusión que será la base de la sentencia que emita (MORAIS, 2005).
\end{abstract}

Percebe-se que os fatos ou questões contábeis, quando em controvérsia judicial, estão sempre ligados ao patrimônio das entidades ou das pessoas físicas. Nesse sentido, Alberto (1996. p. 46) presta o seguinte esclarecimento: 
Definido que o objeto da Ciência Contábil é o patrimônio, já podemos, logicamente, inferir que a perícia será de natureza contábil sempre que recair sobre elementos objetivos, constitutivos, prospectivos ou externos, do patrimônio de quaisquer entidades, sejam elas físicas ou jurídicas, formalizadas ou não, estatais ou privadas (ALBERTO, 1996).

Sobre o desenvolvimento do trabalho do perito, o que é denominado ciclo do trabaIho pericial contábil, têm-se duas etapas: a preliminar e a de execução. A figura a seguir, apresenta essas etapas e os respectivos procedimentos.

\section{Figura 1 - Ciclo do Trabalho Pericial Contábil}

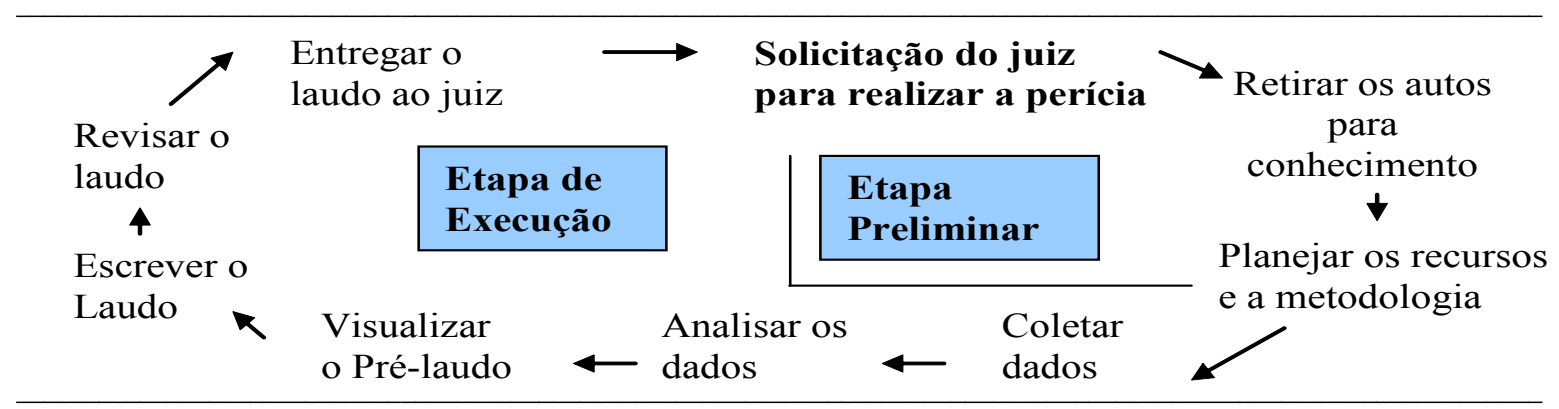

Fonte: (Santos, 2003, p. 91)

Medeiros e Neves Júnior (2004) citando Santos (2003, p. 92) explicam que:

A etapa preliminar corresponde à nomeação do perito e retirada dos autos para análise. Nessa etapa o perito toma conhecimento da ação através da leitura dos autos, determina os objetivos estabelecidos, e estabelece seu planejamento (metodologia e os recursos necessários). A etapa de execução corresponde à aplicação de procedimentos para a coleta de dados necessários à composição do laudo, sua elaboração e entrega. A elaboração do laudo pericial observará a redação de forma clara, objetiva e coerente, e a revisão para corrigir eventuais pontos conflitantes ou falhos, culminando com a entrega do mesmo. Os procedimentos para a coleta de dados objetivam examinar de forma crítica os fatos, aplicando o conhecimento técnico do perito, organizando-os de maneira coerente e por fim, narrando apenas os que tenham relevância para o alcance do objetivo (MEDEIROS; NEVES JUNIOR, 2004).

O perito utiliza-se de técnicas, do conhecimento de ciências, da metodologia e das práticas profissionais para prestar serviços de qualidade. Para obter qualidade, o contador deve estar sempre se especializando, pois a conquista de serviços depende tanto do custo 
quanto da qualidade dos serviços oferecidos. A qualidade dos serviços pode ser entendida não só como boa técnica, mas tambémcomo satisfação do cliente em relação a sua necessidade, que advém da percepção de que o resultado do pedido ficou de acordo com o esperado (ROCHA, 2004, p. 84).

A partir das interpretações doutrinárias de diversos autores, o conceito de Perícia Contábil pode ser sintetizado da seguinte forma: é um trabalho exercido por profissional da área contábil, que, por meio da aplicação de conhecimento científico e notória especialização, traz à superfície fatos ou atos, prestando seu testemunho perante o magistrado ou a outras autoridades com a conclusão do laudo pericial.

\subsection{Perícia Contábil Semijudicial}

É a perícia realizada no meio estatal por autoridades policiais, parlamentares ou administrativas que têm poder jurisdicional por estarem sujeitas às regras legais e regimentais.

Conforme afirma Alberto (2000):

Esta espécie de perícia subdivide-se, segundo o aparato estatal atuante, em policial (nos inquéritos), parlamentar (nas comissões parlamentares de inquéritos ou especiais) e administrativo-tributária (na esfera da administração pública tributária ou conselhos de contribuintes), e classifica-se em semijudiciais porque as autoridades policiais, parlamentares ou administrativa têm algum poder jurisdicional, ainda que relativo e não com a expressão e extensão do poder jurisdicional classicamente enquadrável como pertencente ao poder judiciário e, ainda, por estarem sujeitas a regras legais e regimentais que se assemelham às judiciais (ALBERTO, 2000).

\subsubsection{Perícia Criminal Contábil}

Os métodos de investigações criminais acompanharam a evolução das ciências ao longo dos tempos e, assim como nas diversas áreas do conhecimento, tornaram-se imprescindíveis o desenvolvimento, a especialização e a adequação às novas práticas criminais, a exemplo das investigações de Inteligência Financeira no âmbito dos crimes financeiros cometidos contra o Estado Brasileiro.

A criminalística, a qual cabe o exame de corpo de delito, utiliza-se de vários campos da ciência para atingir seus objetivos. No tocante à apuração dos crimes financeiros, essa função recai [...] sobre a ciência contábil (DOREA; STUMVOLL; QUINTELA, 2003, p. 203). De forma explícita, o artigo 158 do Código de Processo Penal determina que "quando a infração deixar vestígio será indispensável o exame de corpo de delito, direto ou indireto, não podendo supri-lo a confissão do acusado". Conforme estabelece o artigo 564 
do Código de Processo Penal, nos casos em que as autoridades não observarem o cumprimento do exame de corpo de delito, acarretará a nulidade conforme consta, "a nulidade ocorrerá nos seguintes casos [...] por falta das fórmulas ou dos termos seguintes [...] o exame de corpo de delito nos crimes que deixem vestígios [...]". (BRASIL, 1998).

Diferentemente da Perícia Contábil Judicial, determinada pelo magistrado, a Perícia Criminal Contábil é exercida pelo aparelho estatal e determinada pelas autoridades policiais dos Institutos de Criminalística. Nos âmbitos estaduais são executadas pelas polícias civis dos Estados e Distrito Federal; no âmbito nacional, pelo Instituto Nacional de Criminalística do Departamento de Polícia Federal.

Cunha (2003, p. 09) afirma que o trabalho do perito tem como objetivo a prova material na busca dos valores e autoria do delito praticado e enumera que os principais exames realizados no Instituto Nacional de Criminalística - INC referem-se às "movimentações bancárias, financiamentos, operações financeiras e orçamentárias, vistorias e avaliações, mercados de capitais [...] e superfaturamento em obras de serviços públicos".

Nos crimes financeiros, que geralmente envolvem transferências de recursos para aplicações em paraísos fiscais, por meio de instituições financeiras, as análises de extratos bancários, além da documentação contábil, tornam-se indispensáveis para traçar a rota do crime. Diante da necessidade, a quebra do sigilo bancário é determinada pela justiça e ocorre conforme fluxogramas a seguir:

\section{Figura 2 - Quebra do sigilo bancário}

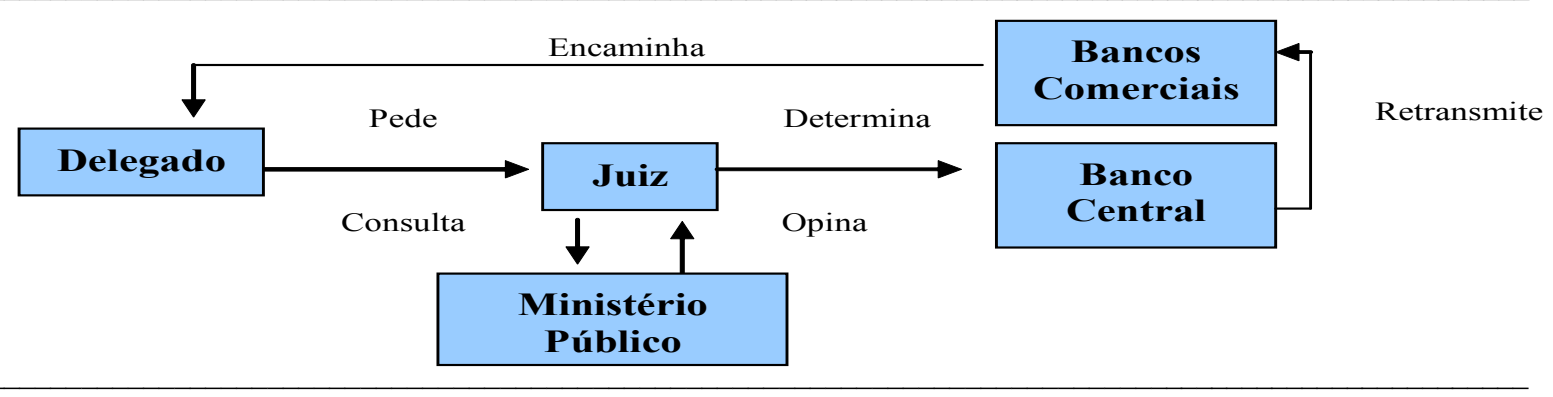

Fonte: (CUNHA, 2003) - INC/DPF

O processo de quebra do sigilo bancário se inicia quando, nos autos do processo, há indícios de crimes financeiros ou outros de natureza relevante. A autoridade competente, nesse caso o delegado de polícia, peticiona ao juiz a quebra do sigilo bancário e, nesse momento, o magistrado consulta o Ministério Público, o qual opina sobre o fato. Por fim, o juiz o determina ao Banco Centra, que retransmite aos bancos comerciais o mandado para cumprimento e posterior envio dos dados às autoridades competentes. 
Figura 3 - Pedido Pericial

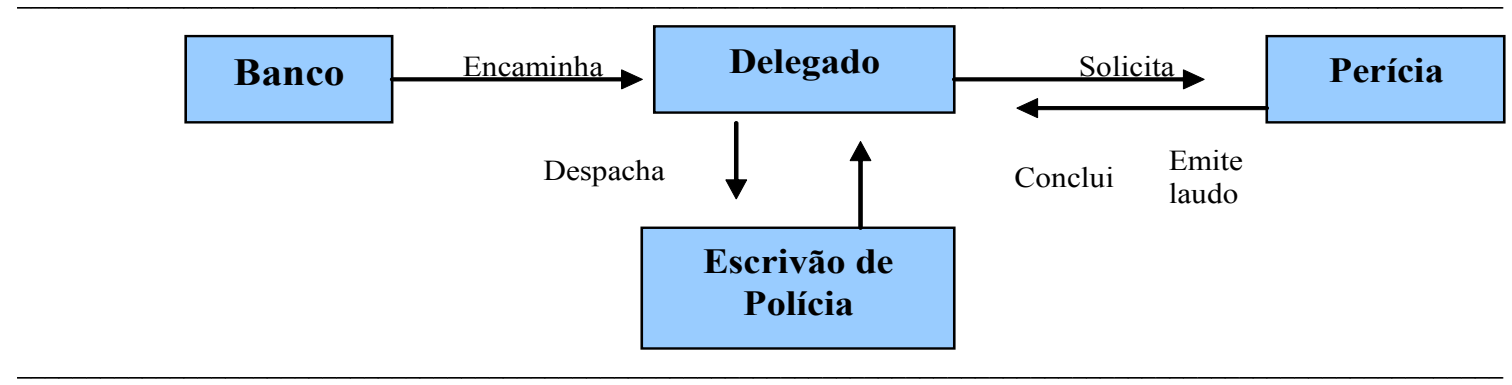

Fonte: (CUNHA, 2003) - INC/DPF

De posse dos dados bancários, o delegado despacha ao escrivão, para efeito de controle, ao mesmo tempo em que solicita a análise à Perícia Criminal Contábil e aos institutos de perícia, enviando-lhes os dados bancários. A posteriori, os peritos designados fazem as análises e emitem o laudo pericial.

Segundo norma editada pelo Conselho Federal de Contabilidade "o laudo pericial contábil e o parecer pericial contábil têm por limite os próprios objetivos da perícia deferida ou contratada." (NBC TP 01, 2009). Nesta modalidade de perícia - criminalística - não há a figura dos assistentes técnicos das partes, logo, não existe o parecer contábil, porém há a necessidade dos laudos serem assinados por dois peritos criminais.

De acordo com Espíndula (2006), "os encarregados da execução pericial, no âmbito da perícia criminal, devem ser profissionais com formação acadêmica, contratados pelo Estado mediante concurso público específico para esta finalidade". "No processo penal diferente do civil - as perícias contábeis serão realizadas por dois peritos oficiais, designados pelo chefe da seção de criminalística onde estiverem lotados, ou seja, não depende de autoridade judiciária" (DOREA; STUMVOLL; QUINTELA, 2003, p. 203).

Quanto à responsabilidade do perito, Espíndula (2006) esclarece que "o perito, no exercício da sua função, deve se dividir em duas partes distintas. Aquela do ponto de vista legal, em que são exigidas algumas formalidades e parâmetros para sua atuação como perito; e as de ordem técnica, necessárias para desenvolver satisfatoriamente os exames técnico-científicos que the são inerentes".

Segundo Dorea, Stumvoll e Quintela (2003, p. 20) "o perito tem sempre presente em suas atitudes, no exercício da função pericial, a grande responsabilidade que pesa em seus ombros pelo trabalho que desenvolve".

O laudo pericial é o produto final da perícia. Jesus (2003, p. 11) o descreve da seguinte forma: "o resultado do trabalho pericial encontra-se finalizado no laudo, que consiste na fiel apresentação da metodologia científica e na constatação das diligências efetuadas, com conclusões e respostas fundamentadas sobre a matéria que foi submetida a exame pelo perito". 
Dorea, Stumvoll e Quintela (2003, p. 20) afirmam que o laudo poderá ser a peça principal e fundamental para condenar ou inocentar o réu. Segundo eles, o perito só poderá concluir ou fazer qualquer afirmação em seu laudo se puder lastrear tal assertiva com uma justificativa técnico-científica.

\subsubsection{Crime organizado}

O legislador não definiu o significado da expressão "crime organizado" com a publicação da Lei n. 9.034/1995, restando aos juristas e à jurisprudência defini-lo da melhor forma possível. Devido à falta de conceito expresso na legislação, alguns órgãos adotaram os seus próprios conceitos.

Segundo Oliveira (2004), o Federal Bureau of Investigations (FBI), um dos maiores órgãos de Polícia dos Estados Unidos da América, define crime organizado como qualquer grupo que tenha uma estrutura formalizada cujo objetivo seja a busca de lucros por meio de atividades ilegais. As Nações Unidas consideram organizações criminosas como sendo aquelas que possuem vínculos hierárquicos, usam da violência, da corrupção e da lavagem de dinheiro para continuarem no poder das atividades ilícitas.

A Academia Nacional de Polícia (2005) enumera dez características do crime organizado, conforme figura abaixo:

\section{Figura 4 - As características do crime organizado}

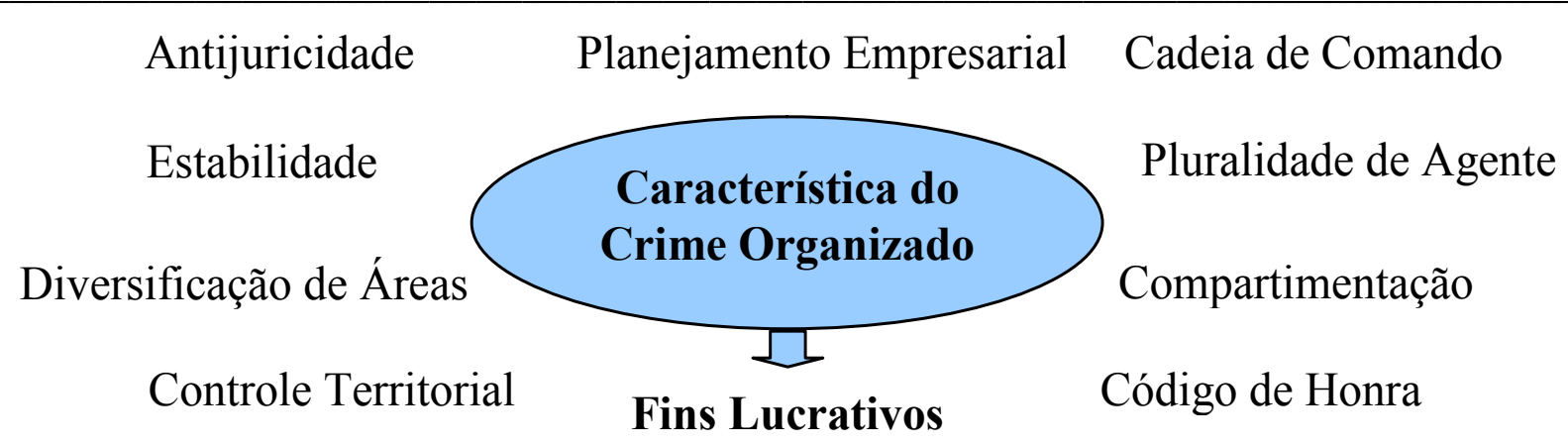

Fonte: Academia Nacional de Polícia-ANP (2005)

A mola propulsora do crime organizado gira em torno da lucratividade das atividades ilícitas. Para alcançar esse objetivo, as organizações possuem uma série de características, as quais permitem a funcionalidade de suas atividades.

Antijuricidade - Constitui uma das características das organizações que se associam para as práticas de crimes, e dessa forma, agem na contramão das determinações legais, portanto, praticam atos antijurídicos. 
Estabilidade - Essa característica tem como fator principal a duração, ou seja, são indivíduos que vivem desse meio de atividade ilegal. A permanência do vínculo da associação é elemento essencial para tipificá-los como organizações criminosas.

Diversificação de áreas - São as ramificações das organizações. Assim como nas atividades lícitas, os investidores no mundo criminal tentam diversificar as aplicações dos recursos para obterem maior proteção do capital aplicado, haja vista alguma crise. Diversificam-se as áreas de atuação tendo em vista a própria sustentabilidade do grupo.

Controle Territorial - São as regiões ou áreas controladas. As organizações usam do poder da violência e determinam os limites estabelecidos para cada grupo, por exemplo, nas favelas cariocas, um grupo de um morro não interfere nas atividades territoriais do outro.

Planejamento - Nos negócios lícitos o planejamento constitui um pilar básico de todas as atividades empresariais. As organizações criminosas não diferem das organizações legais quanto ao planejamento, que serve para minimizar os custos e os riscos a fim de maximizar os lucros.

Cadeia de comando - Está ligada a uma forte hierarquia e disciplina. Ela está fundamentada no argumento da violência, e suas decisões são centralizadas e verticais, ou seja, de cima para baixo.

Pluralidade de Agentes - Para a tipificação legal de crime organizado exige-se a participação de pelo menos quatro indivíduos, logo, a pluralidade de agentes está entre as características indispensáveis para determinar essas associações delituosas como crime organizado.

Compartimentação - Essa característica serve para dividir em etapas ou níveis os sistemas operacionais com o intuito de dificultar ao máximo a fiscalização por parte do estado.

Código de Honra - Diz respeito à disciplina e a lealdade aos chefões. São regras impostas por códigos próprios e, geralmente, vale o que está escrito, por exemplo, a lei do silêncio imposta aos que forem presos.

A demonstração acima retrata a magnitude com que informalmente se estabeleceram no cenário econômico as diversas modalidades de criminalidades. As organizações criminosas estão voltadas para atingir a meta da lucratividade e da multiplicação do lucro por meio de "investimentos" em novas modalidades de crimes, resumem-se assim as principais características dessas organizações.

\subsubsection{Lavagem de Dinheiro}

O Conselho de Controle de Atividades Financeiras - COAF - criado pela lei $\mathrm{n}^{\circ}$. 9.613/1998 - conceitua a lavagem de dinheiro como sendo o processo pelo qual o criminoso transforma recursos ganhos em atividades ilegais em ativos com uma origem aparentemente legal (COAF, 2006). Esse processo que consiste em transformar o bem ilícito em um bem aparentemente lícito, geralmente envolve várias transações com o objetivo de dificultar ao máximo o rastreamento do processo de ilegalidade. No Brasil, o órgão incumbido de 
exercer a fiscalização das transações é o próprio COAF, criado no âmbito do Ministério da Fazenda, com a finalidade de disciplinar, aplicar penas administrativas, receber, examinar e identificar as ocorrências suspeitas de atividades ilícitas previstas em lei.

Com o avanço desse tipo de criminalidade, passando de local a transnacional, diversos países têm criado agências governamentais responsáveis por atuar diretamente na repressão à lavagem de dinheiro. Essas agências são chamadas mundialmente de Unidades Financeiras de Inteligência - FIU (Financial Intelligence Unit). Para alcançar os objetivos da lavagem dos recursos, os criminosos realizam basicamente três processos dinâmicos e planejados: $\left(1^{\circ}\right)$ o distanciamento dos recursos de sua origem; $\left(2^{\circ}\right)$ planejamento para dificultar o rastreamento do processo e, $\left(3^{\circ}\right)$ com o êxito das operações, a disponibilidade dos recursos envolvidos para os criminosos ou suas organizações em recursos considerados aparentemente legais. Esse processo compreende basicamente três fases da lavagem, independente de sua frequência, segundo o COAF.

\section{Figura 5 - Fases da Lavagem de Dinheiro}

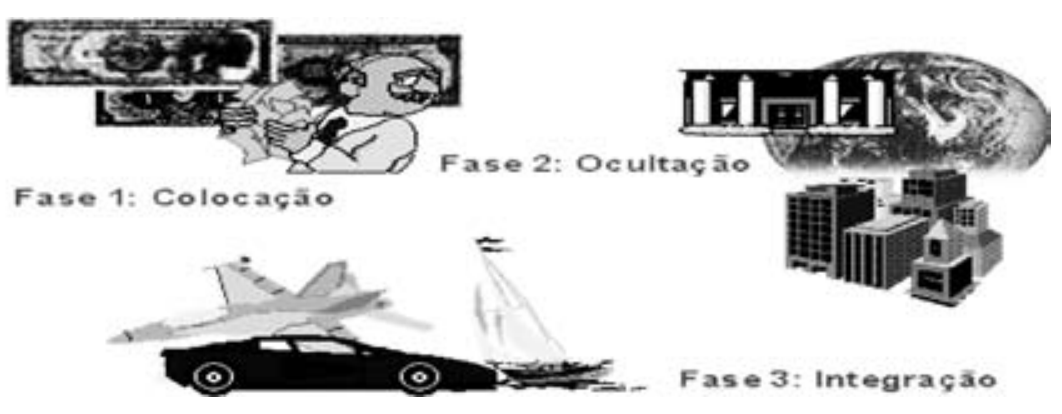

Fonte: $\mathrm{COAF} / 2006$

Colocação - Consiste na colocação do dinheiro no sistema econômico, geralmente em locais onde o sistema financeiro possui regras mais permissivas, efetuadas por meio de depósitos, compra de instrumentos negociáveis e compras de bens.

Ocultação - Consiste em dificultar ao máximo o processo de rastreamento contábil dos recursos aplicados, quebrando a cadeia de forma inteligente, movimentando-os de modo eletrônico e transferindo os ativos para contas anônimas ou realizando depósitos em contas fantasmas.

Integração - Com as operações realizadas e consumadas, os ativos ilícitos são incorporados ao sistema econômico, passando a exercer fins aparentemente lícitos com objetivo de movimentar a economia local.

Os setores mais visados pela lavagem de dinheiro, segundo o COAF, são as instituições financeiras, paraísos fiscais, bolsas de valores, companhias seguradoras, mercados imobiliários, jogos e sorteios, comércio de jóias, pedras e metais preciosos, obras de arte e outros. 


\subsubsection{Exemplos de Crimes Financeiros (Evasão de Divisas)}

Os dois casos apresentados em seguida são apenas exemplos da aplicabilidade da Perícia Criminal Contábil que demandaram laudos periciais durante as investigações criminais e, nesse caso, da relevante contribuição das técnicas periciais nas investigações criminais.

A seção seguinte foi elaborada com base nas referências dos peritos Lopes (2006), e Montenegro e Bellucco (2006) do Instituto Nacional de Criminalística do Departamento de Polícia Federal.

\subsection{Caso do Banco Banestado}

O caso Banestado faz parte da história dos inúmeros escândalos ocorridos no Brasil, e demandou uma das maiores investigação de evasão de divisas e lavagem de dinheiro dos últimos tempos. Com a implantação do Plano Real em 1994 e a consequente paridade entre o real e o dólar, um grande número de brasileiros se dirigiu às cidades da tríplice fronteira Brasil, Paraguai e Argentina, mais especificamente à cidade de Foz do Iguaçu, no estado do Paraná, e à Ciudad Del Este, no Paraguai, com a finalidade de efetuar aquisições no comércio local.

Essas aquisições não passavam de um comércio de intensa movimentação com grande fluxo de moeda nacional e estrangeira. Logo, com o grande vulto dos negócios, foram identificados dois esquemas de evasão de divisas e lavagem de dinheiro: primeiro, o dos carros fortes, e segundo, o dos "laranjas".

O esquema dos carros fortes acontecia da seguinte forma: os carros fortes transportavam reais do Paraguai para o Brasil com o propósito de depositá-los em contas CC5 (carta circular $n^{\circ} .5$, destinada a pagamentos/recebimentos em moeda nacional entre os residentes no exterior, revogada em 1996, pela circular 2.677) em bancos brasileiros, e, em seguida, eram convertidos em dólares e enviados ao exterior. As autoridades brasileiras passaram a observar que o número de carros-fortes que passavam pelo controle de fronteira era muito menor que aqueles que chegavam às agências bancárias brasileiras naquela cidade, ou seja, outros carros-fortes, transportando dinheiro do crime organizado eram colocados em conjuntos com os que passavam pelo controle de fronteira. Assim surgiram os primeiros indícios de um dos principais esquemas de lavagem de dinheiro.

O outro esquema de lavagem de dinheiro aconteceu com a abertura de inúmeras contas bancárias em nome de "laranjas" - pessoas que cediam ou tinham seus nomes utilizados por doleiros - com o intuito de recepcionar recursos irregulares do crime organizado. Esses recursos eram repassados por meio das contas CC5 paras as casas de câmbios e instituições financeiras paraguaias, convertidos em dólares e depositados em paraísos fiscais, promovendo, assim, a evasão de divisas e ocultando a sua real origem. Segundo os peritos Monteiro e Belluco (2004), esses esquemas de evasão de divisas demandaram a abertura de mais de 300 inquéritos e a elaboração de inúmeros laudos relacionados às contas "laranjas" 
com a finalidade de identificar os depositantes, o destino dos recursos e avaliar a capacidade financeira daquelas pessoas que movimentaram tais valores em suas contas correntes.

\subsubsection{Desvios de Verbas da SUDAM e SUDENE}

Os escândalos envolvendo desvios de verbas públicas também são constantes, até mesmo os recursos destinados ao desenvolvimento das regiões carentes são desviados ou apropriados por organizações criminosas. Analisando o passado, não tão distante, é possível nos lembrar de casos como da Superintendência de Desenvolvimento do Amazonas - SUDAM e Superintendência de Desenvolvimento do Nordeste - SUDENE.

Segundo as investigações, os desvios da SUDAM e SUDENE chegaram a cinco bilhões de reais. Esse valor, em sua grande parte, foi enviado aos paraísos fiscais, promovendo a evasão de divisas e lavagem de dinheiro, transformando os recursos, aparentemente em recursos legais. Os recursos eram desviados em um esquema de aprovação de projetos de interesse das organizações criminosas, superfaturamento de serviços prestados- por empresas em nomes de laranjas -, de pagamento por benfeitorias já existentes ou aquisição e entrega de materiais usados no lugar de novos.

O perito Lopes (2006) relata que após esses anos, os inquéritos abertos pelo Departamento de Polícia Federal, baseados em laudos de perícias de engenharia e de contabilidade, vêm apontando para um índice superior a $80 \%$ dos empreendimentos com algum tipo de irregularidade grave, e em especial, os superfaturamentos de despesas públicas.

\subsubsection{Ciclo Lógico da Organização Criminosa}

A partir dos exemplos apresentados, verifica-se que dentre outras maneiras operacionais, as organizações criminosas geralmente constituem as suas transações de acordo com o fluxograma abaixo, não o estabelecendo como regra, mas sim como os caminhos mais prováveis para a realização das operações.

\section{Figura 6 - Ciclo lógico da lavagem de dinheiro}

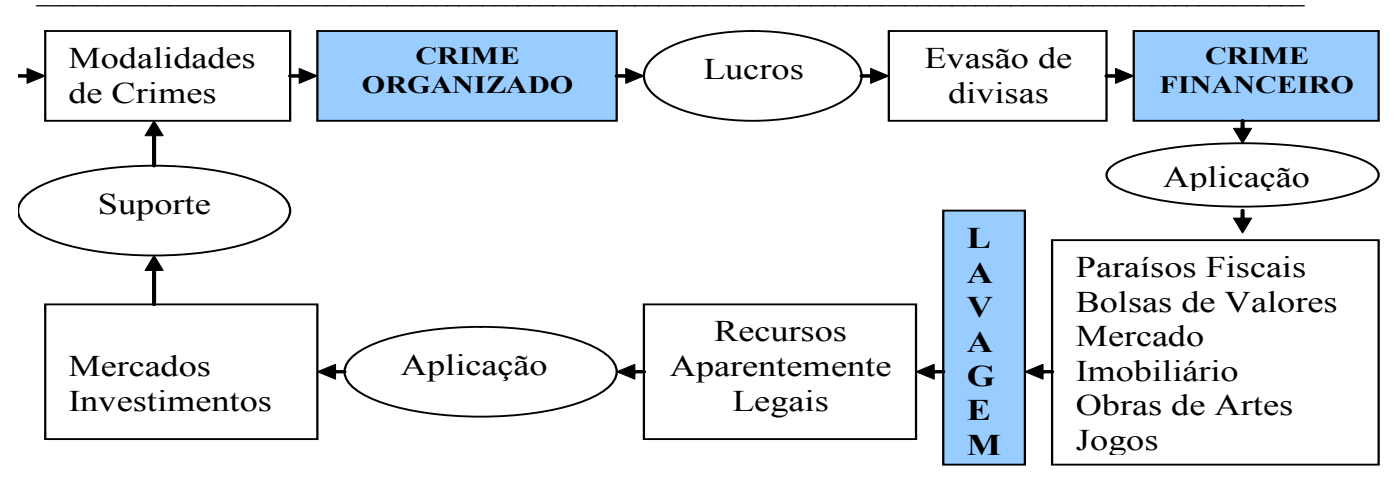

Fonte: Elaboração própria 
Com a associação de indivíduos no intuito de cometer atos ilegais, forma-se a célula do crime organizado. O principal objetivo desses grupos é a lucratividade. Com os rendimentos apurados, praticam as evasões de divisas e posterior aplicação nos paraísos fiscais, bolsas de valores, mercados imobiliários, obras de artes e jogos. Após o prazo de aplicação, fazem os resgastes desses mesmos recursos, transformando-os em aparentemente legais. De posse dos recursos, aplicam novamente no mercado, porém de forma legal e permanente, movimentando as economias de determinadas regiões.

O ciclo apresentado permite evidenciar que tanto o caso do Banestado quanto o da SUDAM / SUDENE foram constituídos nessa lógica operacional, uma vez que as organizações criminosas se associaram com o objetivo de obter lucro por meio de práticas criminais. Com a evasão de divisas cometeram crimes, entre eles, os financeiros, utilizando-se da lavagem de dinheiro na tentativa de transformar os recursos de origem ilícita em recursos aparentemente lícitos.

\section{PESQUISA DE CAMPO}

\subsection{Classificação da Pesquisa e sua Caracterização}

Esta pesquisa foi classificada como pesquisa de campo e o instrumento utilizado para a coleta de dados foi questionário de pesquisa estruturado em duas partes. A parte " $A$ " apresentou as características dos usuários e a parte "B", as afirmações e perguntas, sendo 13 (treze) questões fechadas e 01 (uma) questão aberta.

A pesquisa compreendeu uma amostra de 35 (trinta e cinco) policiais, sendo 07 (sete) Delegados, 10 (dez) Escrivães e 18 (dezoito) Agentes de Polícia, todos exercendo suas funções na Área de Inteligência nas divisões da Diretoria de Combate ao Crime Organizado do Departamento de Polícia Federal. Esses respondentes foram escolhidos em razão do trabalho investigativo que desenvolvem em relação às ações criminosas e por serem usuários dos laudos periciais.

Por motivo de segurança, em se tratando de questão de Inteligência Policial, não foi possível revelar a população em relação à amostra, de forma a evitar a exposição pública da quantidade de operadores. A pesquisa não abordou a identificação dos respondentes e se constituiu meramente para fins acadêmicos com questões direcionadas à Perícia Criminal Contábil.

É importante ressaltar que o trabalho possui 35 (trinta e cinco) registros, 22 (vinte e duas) variáveis e 770 (setecentos e setenta) dados. Para análise dos dados e testes das suposições elaboradas foram delineados os seguintes passos: elaboração do questionário, aplicação do questionário, cálculos das frequências e cruzamentos de dados, utilização de técnica estatística multivariada por meio da análise de cluster. Para análise dos dados foi utilizado o software SPSS (Statistical Package for the Social Sciences) versão 12.0 for Windows. 


\subsection{Resultados da Pesquisa}

As informações apresentadas a seguir foram obtidas por meio das respostas resultantes da aplicação dos questionários aos investigadores da área de Inteligência Policial. Os resultados foram discutidos em três blocos: características dos respondentes, análise das respostas e respostas por agrupamentos (clusters).

\subsubsection{Características dos Respondentes}

Os respondentes possuem, na sua maioria, em função dos cargos e atividades exercidos, formação em ciências jurídicas. São graduados em Direito: 100\% dos Delegados, 90\% dos Escrivães e 55\% dos Agentes de polícia. É importante ressaltar que dos 35 (trinta e cinco) respondentes, apenas um não tem formação superior. Dentre os respondentes, vinte e sete são do sexo masculino e oito do sexo feminino.

\subsubsection{Análises das Respostas sem Definição de Agrupamento}

Nesta seção, os dados foram analisados a partir das respostas dos usuários da informação quando da utilização dos laudos periciais nos inquéritos. São eles: os Delegados, os Escrivães e os Agentes de Polícia.

Para a análise dos resultados, houve a utilização da escala Likert, representando: (1) discordo totalmente, (2) discordo, (3) nem concordo e nem discordo, (4) concordo e (5) concordo totalmente, em cada uma das questões formuladas. Para discussão dos resultados consideraram-se as escalas "concordo" e "concordo totalmente" como aceitação da afirmativa, "nem concordo e nem discordo" como indiferente e "discordo" ou "discordo totalmente" como não aceitação da afirmativa proposta. As questões foram aplicadas conforme demonstração abaixo, e, em consequência, obteve-se as seguintes respostas dos respondentes.

Por meio das análises dos laudos desenvolvidos pelos peritos é possível ter uma boa dimensão (visualização) dos trabalhos desenvolvidos pelo Instituto Nacional de Criminalística.

\section{Gráfico 01 - Visualização dos Trabalhos Periciais (em\%)}

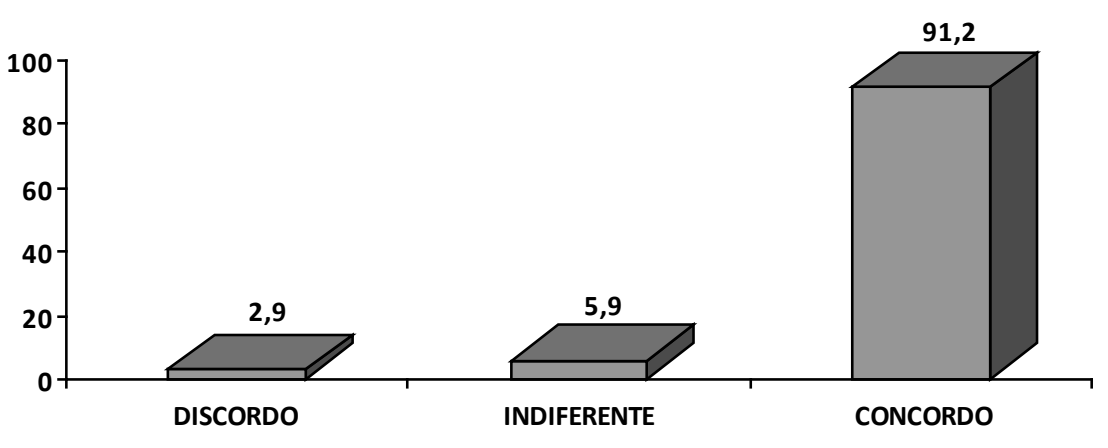

Com o resultado, verificou-se que $91,2 \%$ dos entrevistados concordam com a afirmação. Esse percentual demonstra que por meio dos laudos periciais é possível identificar 
o trabalho desenvolvido pelos peritos, conforme afirma Jesus (2003, p. 11),"o resultado do trabalho pericial encontra-se finalizado no laudo, que consiste na fiel apresentação da metodologia científica e na constatação das diligências efetuadas, com conclusões e respostas fundamentadas sobre a matéria que foi submetida a exame pelo perito", ou seja, por meio dos laudos emitidos pelo Instituto Nacional de Criminalística, na visão dos entrevistados, é possível visualizar os trabalhos desenvolvidos pelos peritos sobre o aspecto científico da produção da prova pericial.

Devido à exigência da qualidade dos trabalhos periciais, os entrevistados foram questionados se os textos dos laudos proporcionam uma leitura fácil sobre o assunto em pauta.

\section{Gráfico 02 - Qualidade do Laudo Pericial (em\%)}

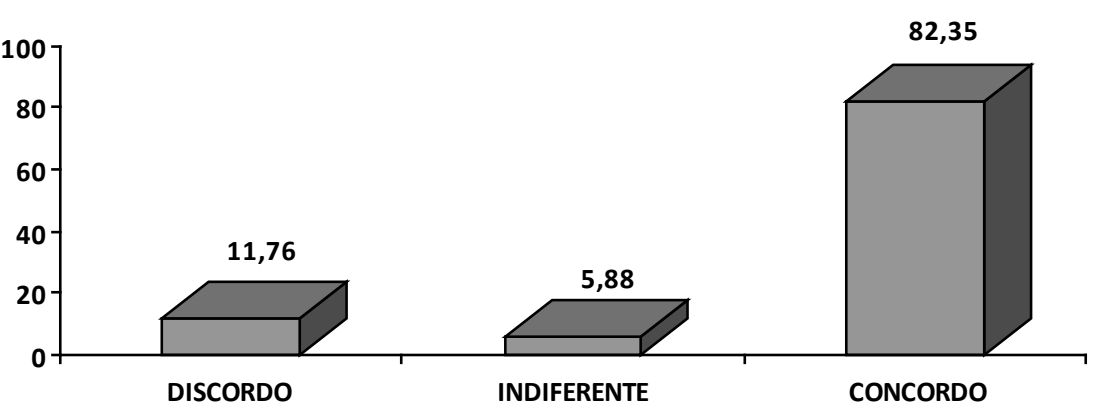

Constatou-se que $82,35 \%$ dos entrevistados concordam que os textos proporcionam uma leitura fácil, demonstrando que os laudos são transcritos com objetividade e coerência no sentido de atender com qualidade os serviços prestados e satisfazer a necessidade de esclarecer as dúvidas. "A qualidade dos serviços pode ser entendida não só pela boa técnica, mais se deve considerar a necessidade e a satisfação do cliente, e [...] que o resultado do seu pedido ficou de acordo com o esperado" (ROCHA, 2004, p. 84), nesse caso, são as respostas dos quesitos solicitados pela autoridade competente.

Os trabalhos periciais costumam responder as dúvidas colocadas nos quesitos, contribuindo no processo investigatório com provas contundentes (fortes).

\section{Gráfico 03 - Respostas dos Quesitos (em\%)}

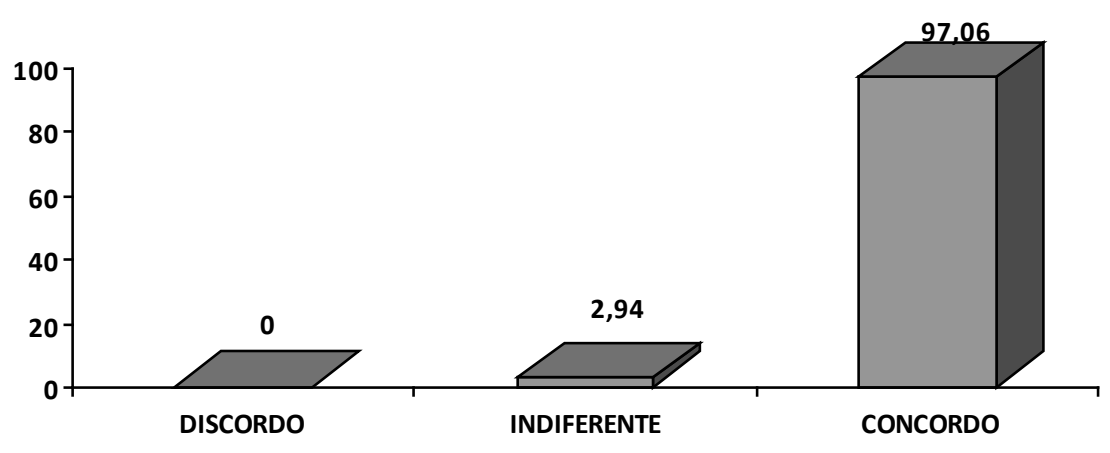


Em resposta ao questionamento sobre os quesitos, $97,06 \%$ concordam que as provas materiais são bem executadas pelos peritos quando das análises dos vestígios. Isso vem ao encontro dos ensinamentos de Magalhães, Souza e Favero (2004, p. 12), eles traduzem que a perícia é "qualquer trabalho de natureza específica, cujo rigor na execução seja profundo. Dessa maneira, pode haver perícia em qualquer área científica ou até em determinadas situações empíricas".

Em relação ao exame de corpo de delito, os respondentes foram questionados se, segundo o Art.158 do Código de Processo Penal, quando a infração deixar vestígio será indispensável o exame de corpo de delito, direto ou indireto, não podendo supri-lo a confissão do acusado. De acordo com a legislação é necessário fazer a perícia. Ela ocorre sempre com rigor no cumprimento do artigo acima.

\section{Gráfico 04 - Execução da Perícia (em \%)}

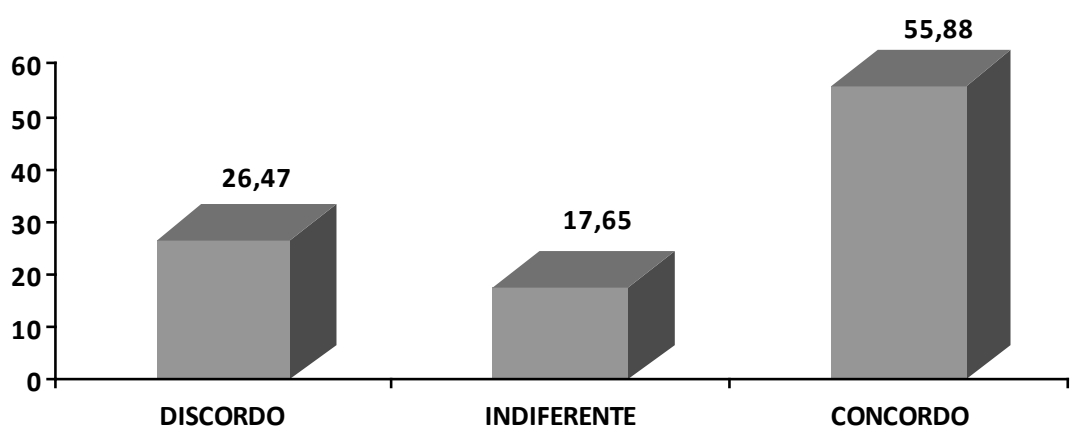

Percebe-se de forma clara que na opinião dos respondentes dessa assertiva, não há uma visão forte de cumprimento das exigências legais quanto ao fato de periciar os delitos. A tudo isso, merece levar em conta as devidas ponderações e as decisões das autoridades competentes em não periciar todos os fatos. Do todo analisado, 55,88\% concordam, $17,65 \%$ nem concordam nem discordam e $26,47 \%$ discordam. Uma boa parte dos respondentes não acredita no cumprimento dessa exigência contida no artigo 158 do Código de Processo Penal, e como consequência do não fazer a perícia, o artigo 564 do Código de Processo Penal diz que:

nos casos em que as autoridades não observarem o cumprimento do exame [...], acarretará a nulidade conforme consta, "a nulidade ocorrerá nos seguintes casos [...] por falta das fórmulas ou dos termos seguintes [...] o exame de corpo de delito nos crimes que deixem vestígios [...]. (BRASIL, 1998). 
Quanto à formação dos contadores, a disciplina Perícia Criminalista Contábil não é obrigatória no currículo de graduação dos Cursos de Ciências Contábeis. Devido à relevância, deveria ser.

\section{Gráfico 05 - Relevância da Disciplina Perícia Contábil Criminalística (em \%)}

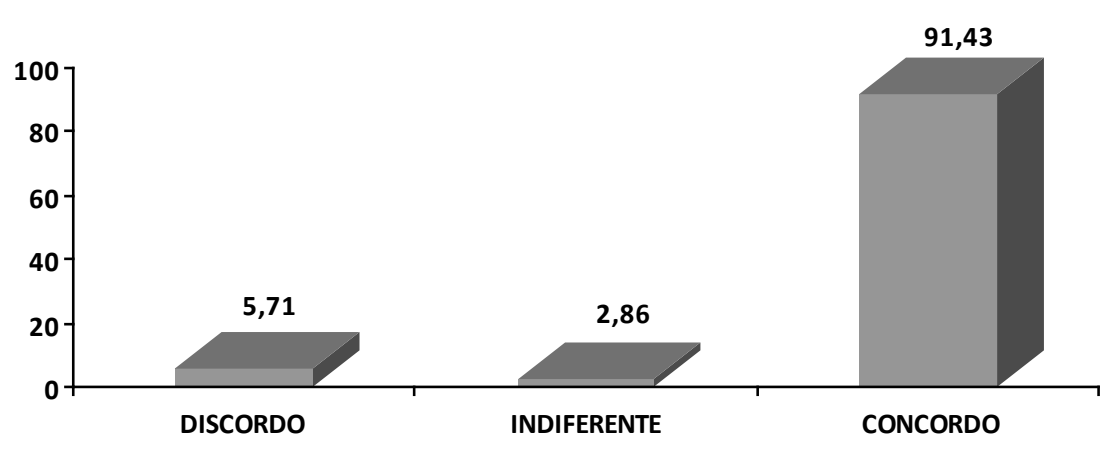

Na opinião dos respondentes, 91,43\% concordam em relação à relevância da aplicação da disciplina Perícia Contábil direcionada para área da criminalística, como relata Alberto (2000):

[...] perícia subdivide-se, segundo o aparato estatal atuante, em policial (nos inquéritos), parlamentar (nas comissões parlamentares de inquéritos ou especiais) e administrativo-tributária (na esfera da administração pública tributária ou conselhos de contribuintes) [...].

Independentemente de ser obrigatória a inclusão da disciplina Perícia Criminalística no currículo de graduação do Curso de Ciências Contábeis, será necessária a formação de bacharéis em Contabilidade que possam dedicar-se a essa função, em especial, auxiliar a justiça na busca de provas.

\section{Gráfico 06 - Inclusão da Disciplina Perícia Contábil Criminal (em \%)}

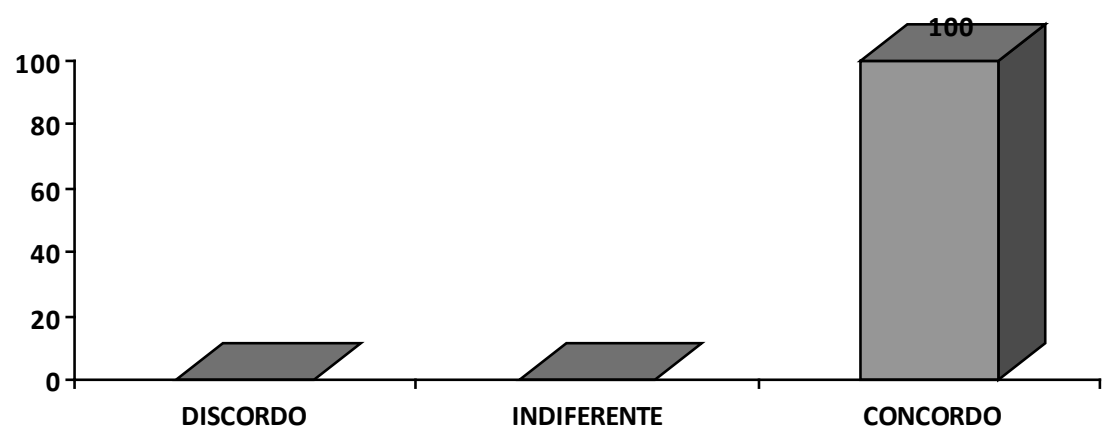


Os respondentes são unânimes em reconhecer a necessidade de se formar bacharéis em Contabilidade para o exercício da função pericial criminal no futuro. Há de se ressaltar que devido ao crescimento das organizações criminosas e suas operações transnacionais, a perícia criminal contábil é um mercado de trabalho em expansão. Dessa forma, haverá necessidade de o estado efetuar as devidas contratações de Peritos Criminais. "Os encarregados da execução pericial, no âmbito da perícia criminal, devem ser profissionais com formação acadêmica, contratados pelo Estado mediante concurso público específico para esta finalidade" (ESPÍNDULA, 2006).

Quanto ao desenvolvimento dos inquéritos policiais e os levantamentos contábeis que servirão de suporte aos processos de crimes financeiros, os dados contábeis são fontes principais utilizadas pelos peritos pertencentes aos quadros funcionais da Polícia Federal para instruir os processos com provas necessárias.

\section{Gráfico 07 - Levantamentos Contábeis (em \%)}

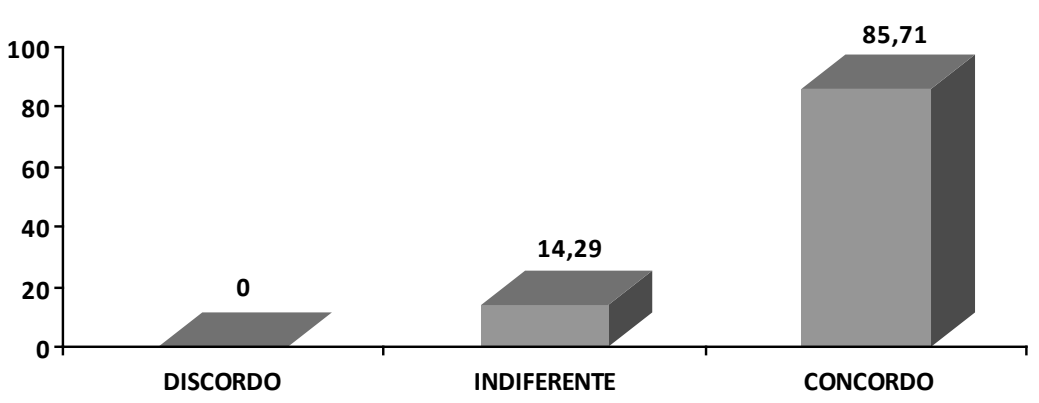

A análise das respostas demonstrou que $85,71 \%$ dos respondentes concordam que os dados contábeis são relevantes no combate aos crimes financeiros. A documentação contábil se tornou fonte importantíssima de informações dos peritos na busca de provas materiais atreladas a várias outras variáveis e associadas ao controle do patrimônio das entidades analisadas. Cunha, (2003, p. 09) afirma que: "O trabalho do perito tem como objetivo a prova material, na busca dos valores e autoria do delito praticado" e enumera que os principais exames realizados no Instituto Nacional de Criminalística INC referem-se às "movimentações bancárias, financiamentos, operações financeiras e orçamentárias, vistorias e avaliações, mercados de capitais [...] e superfaturamento em obras de serviços públicos".

Com o avanço do combate ao crime organizado, o Departamento de Polícia Federal necessitará de profissionais contadores competentes que possam desenvolver trabalhos periciais de natureza contábil. 


\section{Gráfico 08 - Demanda de Peritos Criminais no Futuro (em \%)}

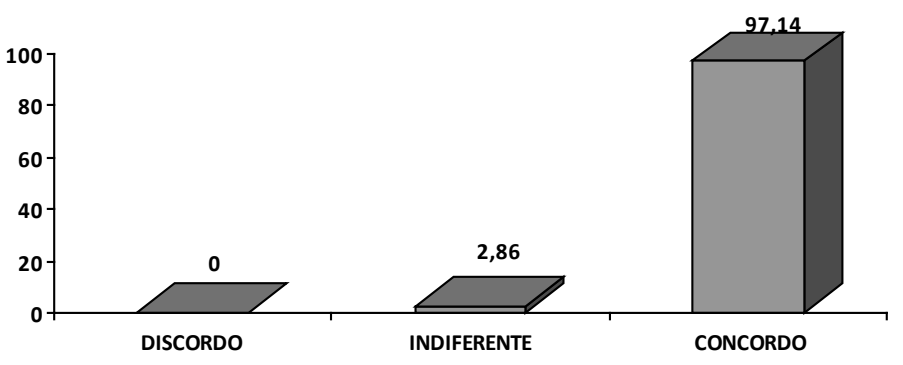

Verificou-se que $97,14 \%$ dos respondentes concordam que futuramente os quadros do Departamento de Polícia Federal necessitarão de profissionais contábeis especializados para dar continuidade às políticas de combate das atividades criminais. Hoog (2005) afirma que o "trabalho pericial é uma prestação de serviço, a qual exige uma especialização" e quanto à qualidade do laudo relatada por Rocha (2004), o perito utiliza-se de técnica, conhecimento de ciências, da metodologia e práticas profissionais para prestar serviços de qualidade.

Quanto à aplicação de novas tecnologias, o mundo complexo dos negócios públicos e privados vem provocando demandas de perícias semijudiciais cada vez mais complexas, o que requererá a produção de provas técnicas altamente sofisticadas. $O$ Instituto de Perícia Criminalística do Departamento de Polícia Federal está equipado tecnologicamente para suportar a demanda.

\section{Gráfico 09 - Tecnologia na Área Pericial (em \%)}

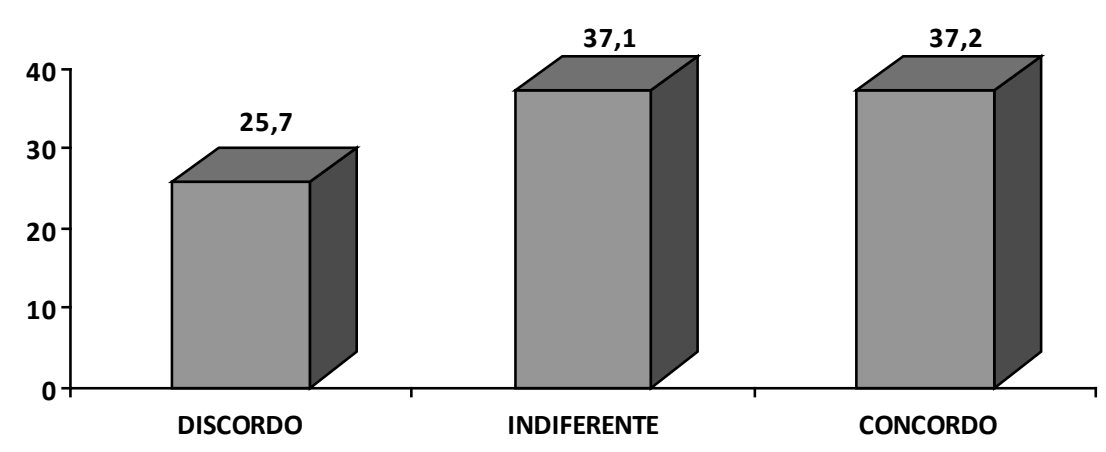

Entre os respondentes há equidade nas respostas. Mas apenas $37,2 \%$ concordam; $37,1 \%$ nem concordam nem discordam e $25,7 \%$ discordam da afirmativa. No entendimento da maioria dos respondentes falta investimento em novas tecnologias. Os investimentos atuais no Instituto Nacional de Criminalística não foram percebidos pelos respondentes ou não houve, sobre as perspectivas deles, maiores notoriedades quanto ao tema. Apenas um terço tem conhecimento dos investimentos atuais. 
As práticas do crime organizado, no Brasil, têm como consequência uma grande evasão de divisas causando grandes danos aos cofres públicos. O governo tem rastreado essas divisas para posterior repatriação ao Estado Brasileiro. A Perícia Criminal Contábil tem uma grande contribuição nessas investigações.

\section{Gráfico 10 - Contribuição da Perícia Criminal Contábil (em \%)}

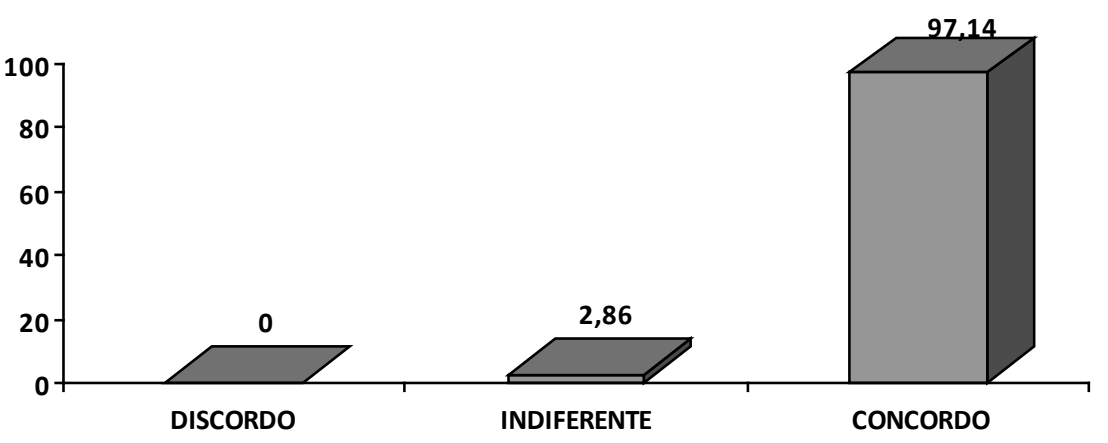

Os respondentes são quase unânimes em responder que a Perícia Criminal Contábil contribui com as repatriações de recursos públicos à administração pública. Dentre eles, $97,14 \%$ concordam, concluindo que os laudos são importantes meios de provas diante das investigações criminais no combate ao crime organizado, com o intuito de descapitalizar as organizações constituídas com essa finalidade. Dorea, Stumvoll e Quintela (2003, p. 20) afirmam que o laudo poderá ser a peça principal e fundamental para condenar ou inocentar um réu. $O$ perito só poderá concluir ou fazer qualquer afirmação em seu laudo se puder lastrear tal assertiva com uma justificativa técnico-científica.

Com o desencadeamento de várias investigações nos últimos anos, o Departamento de Polícia Federal empreendeu um duro combate ao crime organizado, com a prisão de criminosos e o desmantelamento de várias quadrilhas especializadas em crimes financeiros e outros, levando à instância judiciária aqueles que cometeram atos delituosos. Devido a esse fato, houve uma expansão da Perícia Criminal na produção de provas.

\section{Gráfico 11 - Expansão da Perícia Criminalística Contábil (em \%)}

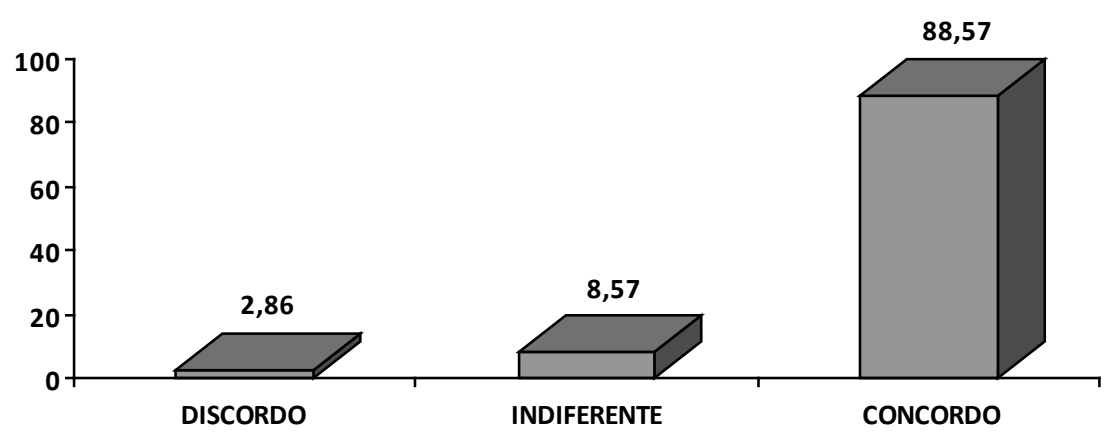


Verificou-se que $86,57 \%$ dos respondentes concordam com a afirmativa. Nos últimos anos, tornaram-se notórias as operações da Polícia Federal deflagradas em várias regiões do país, e, em função disso, houve uma expansão natural da quantidade de exames periciais devido ao volume de materiais apreendidos e, em muitos casos, à necessidade de periciar, têm-se dessa forma as justificativas para tal expansão dos trabalhos desenvolvidos pelos peritos criminais no intuito de auxiliar nos trabalhos judiciais.

Quanto ao trabalho do perito criminal contábil, houve solicitação para que os respondentes atribuíssem nota ao trabalho do perito criminalista contábil.

\section{Gráfico 12 - Trabalho do Perito Criminalista (em \%)}

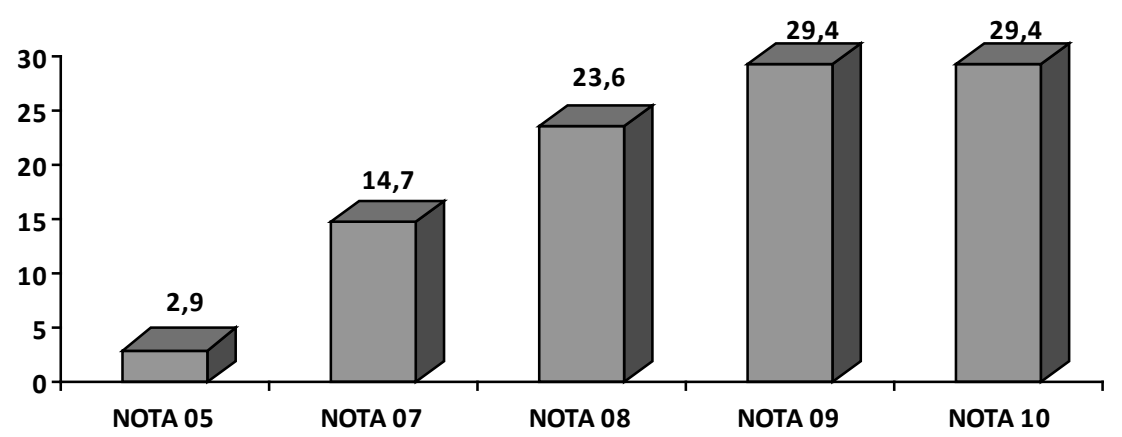

Do total dos respondentes, $2,9 \%$ atribuíram nota cinco; $14,7 \%$, nota sete; $23,6 \%$, nota oito; $29,4 \%$, nota nove e $29,4 \%$, nota dez. As respostas analisadas permitiram concluir que o trabalho pericial desenvolvido pelos peritos do Instituto Nacional de Criminalística tem grande importância quando se trata de combate à criminalidade. "O perito, no exercício de suas funções, deve atentar quanto aos parâmetros de ordem técnica, necessários para desenvolver satisfatoriamente os exames técnico-científicos" (ESPÍNDULA, 2006). Na opinião dos respondentes, esses parâmetros são observados pelos experts contábeis.

Em relação à relevância da perícia criminal contábil, qual a importância da Perícia Criminalística Contábil para a sociedade?

\section{Gráfico 13 - A Importância da Perícia Criminal Contábil para Sociedade (em \%)}

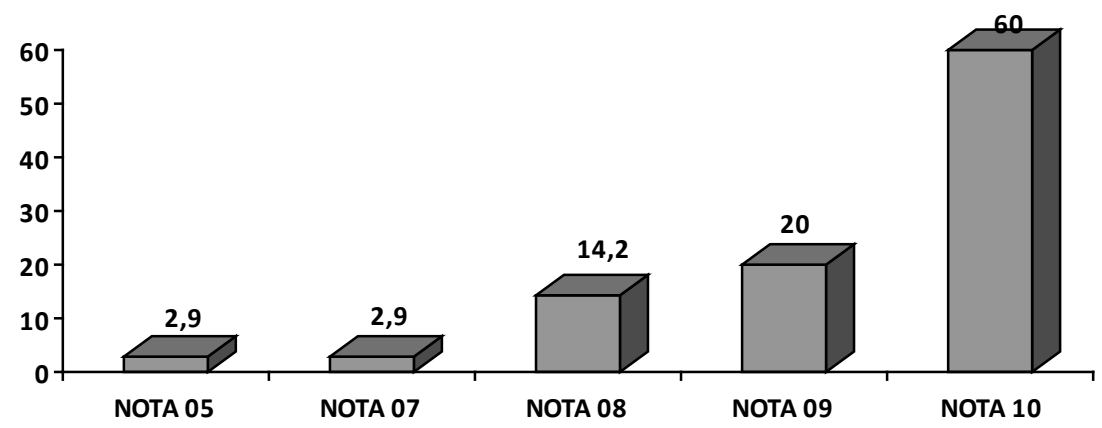


Essa questão procurou identificar o grau de importância da Perícia Criminal Contábil para a sociedade brasileira na opinião dos respondentes. Quanto às respostas, 2,9\% atribuíram nota cinco; $2,9 \%$, nota sete; $14,2 \%$, nota oito; $20 \%$, nota nove e $60 \%$, nota dez.

Observa-se que a Perícia Criminal Contábil encontra-se bem avaliada na opinião dos respondentes quanto à importância perante a sociedade e a contribuição no combate ao crime organizado, com o fulcro na busca por provas materiais contra aqueles que atentarem em desfavor das leis, normas e princípios socialmente aceitos.

Os respondentes teceram algumas declarações a respeito do tema proposto. A seguir, são apresentadas as principais declarações:

1. Realmente a Perícia Contábil criminal é de extrema importância, principalmente no combate aos crimes de lavagem de dinheiro, onde os criminosos tentam dissimular a origem, a colocação e a introdução de recursos nos mercados financeiros dos países em que se praticam esta modalidade de delito e, normalmente, sem a Perícia Contábil torna-se quase impossível o rastreamento do patrimônio ilegal conquistado.

2. A Perícia Contábil, de forma geral, é de suma importância, tanto no âmbito judicial como no policial. A tendência atual nos mostra que a criminalidade está cada vez mais articulada principalmente no âmbito financeiro, o que reforça a real necessidade de aperfeiçoamento na área de Perícia Contábil.

3. Atualmente, com a existência de grandes organizações criminosas, com braços que alcançam até mesmo órgãos governamentais, é de extrema importância o investimento na investigação financeira e contábil de grupos criminosos, para que seja possível quebrar o suporte financeiro e assim desmantelar este tipo de organização.

\subsubsection{Análise das Respostas a Partir da Definição dos Clusters}

Para propiciar o agrupamento dos dados da pesquisa, houve a utilização da técnica estatística multivariada por meio da análise de cluster. O método utilizado foi K-Means clusters do SPSS, com posterior identificação e formação dos agrupamentos.

Como resultado, os casos foram distribuídos em dois agrupamentos:

\section{Tabela 1 - Agrupamentos}

\begin{tabular}{|cr|c|}
\hline Cluster & 1 & 13 \\
& 2 & 16 \\
Total de casos & $\mathbf{2 9}$ \\
Casos não classificados por & 6 \\
ausência de informações & 6 \\
\hline
\end{tabular}


Sobre o percentual de acertos de classificação desses casos nos respectivos agrupamentos, aplicou-se a análise discriminante, o que resultou em um percentual de acertos de $100 \%$, como segue:

Tabela 2 - Classificação dos Resultados

\begin{tabular}{|c|c|c|c|c|c|}
\hline \multirow{2}{*}{\multicolumn{3}{|c|}{ Agrupamentos }} & \multicolumn{2}{|c|}{ Classificação } & \multirow{3}{*}{$\begin{array}{c}\text { Total } \\
13\end{array}$} \\
\hline & & & \multirow{2}{*}{$\begin{array}{c}1 \\
13\end{array}$} & \multirow{2}{*}{$\begin{array}{l}2 \\
0\end{array}$} & \\
\hline Original & Qtde. & 1 & & & \\
\hline & \multirow[t]{3}{*}{$\%$} & 2 & 0 & 16 & 16 \\
\hline & & 1 & 100,0 & 0 & 100,0 \\
\hline & & 2 & 0 & 100,0 & 100,0 \\
\hline
\end{tabular}

Com relação à descrição das características dos casos em seus respectivos agrupamentos, efetuou-se a técnica estatística de análise descritiva. A seguir é apresentada a caracterização desses agrupamentos.

\section{Agrupamento 1}

Esse agrupamento contemplou os Escrivães e Agentes de Polícia. Formado por 12 policiais. Onze deles têm formação em Direito e um em Matemática; com idade entre quarenta e dois e cinquenta e um anos. Quanto ao gênero, onze do sexo masculino e um do sexo feminino.

As respostas desse agrupamento demonstraram que os dozes respondentes expressaram o mesmo nível de pensamento em relação à Perícia Criminal Contábil. As suas respostas têm certa equidade, elas se aproximam quando comparadas umas às outras. Como inferência e possível explicação dessas respostas concordantes podem estar, entre outros aspectos, relacionadas ao tempo de função e idade dos participantes da pesquisa.

\section{Agrupamento 2}

Esse agrupamento contemplou os Delegados, Escrivães e os Agentes, num total de 16 policiais os quais foram agrupados de modo a perceber que eles exercem suas funções entre três e dez anos nos respectivos cargos, têm idade entre vinte e oito e quarenta e sete anos, evidenciando outro nível de pensamento a respeito da Perícia Criminal Contábil.

Com relação às respostas desses participantes, verificou-se que as mesmas foram diversificadas. 


\section{CONCLUSÕES E AGRADECIMENTOS}

A pesquisa permitiu responder a questão inicialmente apresentada. $O$ resultado revelou que a Perícia Contábil, no âmbito criminal federal, dentre as suas atribuições e na visão dos respondentes, exerce caráter de suma importância em relação ao combate do crime organizado.

De acordo com as análises, os laudos elaborados pelos peritos criminalistas foram elaborados com objetividade e clareza, o que os torna peças de fácil entendimento para os usuários que não têm formação específica em Contabilidade. Os laudos produziram as provas necessárias ao desembaraço dos fatos em controvérsia quando solicitados pelas autoridades competentes no âmbito das investigações ligadas aos crimes financeiros.

A pesquisa também revelou a necessidade de formação de profissionais para atuarem na área criminal no futuro, com o objetivo de auxiliar as decisões dos magistrados. Os trabalhos periciais desenvolvidos pelos peritos e, principalmente, o reconhecimento pelos usuários da informação pericial, mostram, de certa maneira, a contribuição da Perícia Criminal Contábil para a sociedade como um todo, no combate à criminalidade.

Em consequência, devido à importância desses profissionais, haverá a necessidade, nos meios acadêmicos, de se formarem contadores com conhecimento em Perícia Contábil direcionada à área da criminalística.

A interface dessa disciplina, Perícia Criminal Contábil, com os cursos de graduação em Ciências Contábeis poderá ser instituída por meio de acréscimo de carga horária para interposição de pelo menos um capítulo de Perícia Contábil direcionado à Criminalística.

Além dessas conclusões, é importante destacar que:

Devido à expertise das organizações criminosas na tentativa de ocultar o rastreamento do processo, em especial na lavagem de dinheiro, a Perícia Criminal Contábil tornou-se ferramenta indispensável na obtenção de provas contra as ações da criminalidade.

As perícias contábeis realizadas nos casos do banco Banestado e SUDAM/SUDENE permitiram visualizar o processo utilizado pelos criminosos no âmbito das investigações, conforme relatado pelos próprios peritos do Instituto Nacional de Criminalística.

Agradecimentos:

Aos usuários da informação contábil pela disposição de prestar as devidas informações durante a pesquisa;

À Universidade Católica de Brasília - UCB pelo projeto de educação dedicado às pessoas;

Aos meus pais por acreditar em um sonho de educar cada um dos seus filhos com dignidade e carinho. 


\section{REFERÊNCIAS}

ALBERTO, Valder Luiz Palombo. Perícia Contábil. São Paulo: Atlas, 1996.

Perícia Contábil. São Paulo: Atlas, 2000.

ACADEMIA NACIONAL DE POLÍCIA. Apostila de Polícia de Repressão ao Crime organizado. Brasília, 2005.

BRASIL. Código de Processo Penal. 38. ed. São Paulo: Saraiva, 1998.

Código de Processo Civil. 23. ed. São Paulo: Saraiva, 1993.

CONSELHO FEDERAL DE CONTABILIDADE. Perícias Contábeis. Normas; NBC. TP. 01. Brasília, 2009.

CONSELHO DE CONTROLE DE ATIVIDADES FINANCEIRAS. Cartilha Sobre Lavagem de Dinheiro. Brasília. Disponível em: <http://www.fazenda.gov.br/coaf/portugues/publicacoes/cartilha.htm>. Acesso em: 03 ago. 2006.

CUNHA, Darley Tortelotti da. Ações da Polícia Federal no Combate ao Crime organizado. Caderno da Controladoria, Rio de Janeiro, a. 3, n. 3, nova série, set. 2003.

DOREA, Luiz Eduardo Carvalho; STUMVOLL, Victor Paulo; QUINTELA, Victor. Tratado de Perícias Criminalísticas. Campinas: Millennium, 2003.

D' ÁURIA, Francisco. Revisão e Perícia Contábil. São Paulo: Companhia Editora Nacional, 1953.

ESPINDULA, Alberi. Função Pericial do Estado. Brasília. Disponível em: <http://www.espindula.com.br/default4e.htm>. Acesso em: 12 jun. 2006.

JESUS, Fernando. Inteligência Financeira, Perícia Contábil e o tráfico de drogas. Perícia Federal, Brasília, a.3, n. 14, p. 09 - 11, jun. / jul.2003.

LOPES, Alan de Oliveira. Caso Sudam e Sudene: a fraude que não acabou. Perícia Federal, Brasília, a.6, n. 23, p. $11-14$, jan. / abr. 2006. 
MAGALHÃES, Antonio de Deus Farias; SOUZA, Clóvis; FAVERO, Hamilton Luiz; LONARDONI, Mário. Perícia Contábil: uma abordagem teórica, ética, legal, processual e operacional. São Paulo: Atlas. 2004.

MEDEIROS, Thaís Alves; NEVES JUNIOR, Idalberto José das. A Qualidade do Laudo Pericial Elaborado pelo Perito-Contador na Visão de Magistrados do Rio de Janeiro e Brasília. Anais do 20 Congresso USP de Iniciação Científica. São Paulo: USP, 2005. Disponível em: <http://www.congressoeac.locaweb.com.br/artigos22005/408.pdf>.Acesso em: 25/08/2006.

MONTENEGRO, Eurico Monteiro; BELLUCO, Clênio Guimarães. Caso Banestado e suas ramificações- 7 anos. Perícia Federal, Brasília a. 5, n. 19, p. 6 - 9, nov. / dez. de 2004.

MORAIS, Antonio Carlos. A Busca da Prova Pericial Contábil. Brasília: A.C.Morais, 2005.

ORNELAS, Martinho Maurício Gomes. Perícia Contábil. São Paulo: Atlas, 2003.

Perícia Contábil. São Paulo: Atlas, 2009.

OLIVEIRA, Adriano: Doutorando em Ciências Política Universidade Federal de Pernambuco. Revista Espaço Acadêmico nº. 34 - Março/2004.

ROCHA, Levi de Alvarenga, SANTOS, Nelson dos. Manual de Perícia Contábil Judicial. Goiânia: Max Gráfica e Editora. 2004.

SÁ, Antonio Lopes. Perícia Contábil. São Paulo: Atlas, 2005.

SANTOS, Creusa Maria Alves dos; MELLO, Onice Maria de. Breve discussão sobre a qualidade total em serviços periciais. Revista Brasileira de Contabilidade, Brasília, a. 32, n. 146, p. 91 - 92, mar. / abr. 2003.

SOUZA, Luiz Francisco de Souza. A Análise de Inteligência Criminal e Contábil. Revista Phoenix Magazine, Brasília: Inaugural Edition, 2004. 